\title{
Primary Production: From Inorganic to Organic Carbon
}

Primary production involves the formation of organic matter from inorganic carbon and nutrients. This requires external energy to provide the four electrons needed to reduce the carbon valence from four plus in inorganic carbon to near zero valence in organic matter. This energy can come from light or the oxidation of reduced compounds, and we use the terms photoautotrophy and chemo(litho)autotrophy, respectively. Total terrestrial and oceanic net primary production are each $\sim 50-55$ $\mathrm{Pg} \mathrm{yr}^{-1}\left(1 \mathrm{Pg}=1 \mathrm{Gt}=10^{15} \mathrm{~g}\right.$; Field et al. 1998). Within the ocean, carbon fixation by oceanic phytoplankton $\left(\sim 47 \mathrm{Pg} \mathrm{yr}^{-1}\right)$ dominates over that by coastal phytoplankton ( $\sim 6.5 \mathrm{Pg} \mathrm{yr}^{-1}$; Dunne et al. 2007), benthic algae $\left(\sim 0.32 \mathrm{Pg} \mathrm{yr}^{-1}\right.$; Gattuso et al. 2006), marine macrophytes ( $\sim \mathrm{Pg} \mathrm{yr}^{-1}$; Smith 1981) and chemo(litho) autotrophs $\left(\sim 0.4\right.$ and $\sim 0.37 \mathrm{Pg} \mathrm{yr}^{-1}$ in the water column and sediments, respectively; Middelburg 2011). Much of the chemolithoautrophy is based on energy from organic matter recycling. Since, photosynthesis by far dominates inorganic to organic carbon transfers, we will restrict this chapter to light driven primary production.

Gross primary production refers to total carbon fixation/oxygen production, while net production refers to growth of primary producers and is lessened by respiration of the primary producer. Net primary production is available for growth and metabolic costs of heterotrophs, and it is the process most relevant for biogeochemists and chemical oceanographers. For the time being, we present primary production as the formation of carbohydrates $\left(\mathrm{CH}_{2} \mathrm{O}\right)$ and ignore any complexities related to the formation of proteins, membranes and other cellular components (Chap. 6), because these require additional elements (nutrients). The overall photosynthetic reaction is:

$$
\mathrm{CO}_{2}+\mathrm{H}_{2} \mathrm{O}+\text { light } \rightarrow \mathrm{CH}_{2} \mathrm{O}+\mathrm{O}_{2}
$$


It starts with the absorption of light energy by photosystem II (PSII):

$$
2 \mathrm{H}_{2} \mathrm{O}+\text { light } \stackrel{P S I I}{\rightarrow} 4 \mathrm{H}^{+}+4 \mathrm{e}^{-}+\mathrm{O}_{2}
$$

This reaction yields energy to generate adenosine triphosphate (ATP). The oxygen produced originates from the water and can be considered a waste product of photosynthesis. The protons and electrons generated subsequently react with nicotinamide adenine dinucleotide phosphate $\left(\mathrm{NADP}^{+}\right)$at photosystem I (PSI):

$$
\mathrm{NADP}^{+}+\mathrm{H}^{+}+2 \mathrm{e}^{-} \stackrel{P S I}{\rightarrow} \mathrm{NADPH} .
$$

The energies of NADPH and ATP are then used to fix and reduce $\mathrm{CO}_{2}$ to form carbohydrate.

$$
\mathrm{CO}_{2}+4 \mathrm{H}^{+}+4 \mathrm{e}^{-} \stackrel{\text { RuBisCO }}{\longrightarrow} \mathrm{CH}_{2} \mathrm{O}+\mathrm{H}_{2} \mathrm{O}
$$

This reaction is normally mediated by the enzyme ribulose bis-phosphate carboxylase (RuBisCO).

Primary production is at the base of all life on earth; it is thus important to quantify it and to understand the governing factors. We will first present, at a very basic level, the primary producers. This will be followed by the introduction of the master equation of primary production, based on laboratory studies, and then a discussion of its application to natural systems.

\subsection{Primary Producers}

Primary producers in the ocean vary from $\mu \mathrm{m}$-sized phytoplankton to $\mathrm{m}$-sized mangrove trees. Phytoplankton refers to photoautotrophs in the water that are transported with the currents (although they may be slowly settling). Biological oceanographers usually divide plankton (all organisms in the water that go with the current) into size classes (Table 2.1). Most phytoplankton are in the pico, nano and microplankton range $(0.2-200 \mu \mathrm{m})$. The prefixes pico and nano have little to do with their usual meaning in physics and chemistry. Their small size gives them a high-surface-area-to-volume ratio which is highly favourable for taking up nutrients from a dilute solution. Within these phytoplankton size classes there is high diversity in terms of species composition and ecological functioning. Both small cyanobacteria (Synechococcus and Procholoroccus) and very small eukaryotes (e.g., Chlorophytes) contribute to the picoplankton. Microflagellates from various phytoplankton groups (Chlorophytes, Cryptophytes, Diatoms, Haptophytes) dominate the nanoplankton and differ in many aspects (cell wall, nutrient stoichiometry, 
Table 2.1 Plankton size classes in the ocean

\begin{tabular}{l|l}
\hline Size lass & Name (example) \\
\hline$<0.2 \mu \mathrm{m}$ & Femtoplankton (virus) \\
\hline $0.2-2 \mu \mathrm{m}$ & Picoplankton (bacteria, very small eukaryotes) \\
\hline $2-20 \mu \mathrm{m}$ & Nanoplankton (diatoms, dinoflaggelates, protozoa) \\
\hline $20-200 \mu \mathrm{m}$ & Microplankton (diatoms, dinoflaggelates, protozoa) \\
\hline $0.2-20 \mathrm{~mm}$ & Mesoplankton (zooplankton) \\
\hline $2-20 \mathrm{~cm}$ & Macroplankton \\
\hline
\end{tabular}

pigments, number of flagellae, life history, presence/absence of frustule). While phytoplankton communities can be described in terms of species, size classes or molecular biology data based partitioning units, they can also be divided into different functional types (diatoms because of $\mathrm{Si}$ skeleton, coccoliths with $\mathrm{CaCO}_{3}$ skeleton, $\mathrm{N}_{2}$-fixers, etc.). Unfortunately, taxonomic, functional and size partitionings among phytoplankton groups are not necessarily consistent.

A substantial fraction of the ocean floor in the coastal domain receives enough light energy to sustain growth of photoautotrophs. This includes not only intertidal areas, but also the subtidal. Small-sized photoautotrophs (microphytobenthos, including diatoms and cyanobacteria) are again the dominant primary producers, but macroalgae, seagrass, saltmarsh plants and mangrove trees contribute as well. Seagrasses, saltmarsh macrophytes and mangrove trees have structural components and specialised organs (roots and rhizomes) to tap into nutrient resources within the sediments.

\subsection{The Basics (For Individuals and Populations)}

Carbon fixation by (and growth of) primary producers will be discussed based on the master equation of Soetaert and Herman (2009):

$$
\mathrm{P}=\mu \cdot \mathrm{B} \cdot \mathrm{f}_{\text {lim }}(\text { resources, conditions })
$$

This master equation simply states that production $(\mathrm{P}, \mathrm{mol} / \mathrm{g}$ per unit volume per unit time) is proportional to the biomass $(\mathrm{B}, \mathrm{mol} / \mathrm{g}$ per unit volume) of the primary producer, the actor, which has an intrinsic maximum growth rate of $\mu\left(\right.$ time $\left.^{-1}\right)$ and is limited $\left(0<\mathrm{f}_{\text {lim }}<1\right)$ by either physical conditions (e.g., temperature, turbulence) or resources such as light, nutrients and dissolved inorganic carbon. This equation is simple and generic, and we will show below how it relates to phytoplankton global primary production estimates using remote sensing, to expressions used in numerical biogeochemical models and to exponential growth in the laboratory. 


\subsubsection{Maximum Growth Rate $(\mu)$}

Consider a primary producer in an experiment supplied with all the resources it needs and under ideal conditions, in other words the limitation function $\mathrm{f}_{\text {lim }}$ is equal to one and optimal growth occurs. Equation 2.1 then reduces to the change in $\mathrm{B}$ with time, or production $\mathrm{P}$, is equal to $\mu \cdot \mathrm{B}$ :

$$
P=\frac{d B}{d t}=\mu B
$$

This is the well-known equation for exponential growth:

$$
B=B_{0} e^{\mu t}, \text { or alternatively }: \mu=\frac{1}{t} \ln \frac{B}{B_{0}}
$$

where $\mathrm{B}$ is the biomass at times $\mathrm{t}$ and $\mathrm{B}_{0}$ is the initial biomass. Plotting the logarithm of biomass development as function of time yields then a slope corresponding to $\mu$. Sometimes data are reported as the number of cell divisions (or doublings) per day: $\mu_{d}=\frac{1}{t} \log _{2} \frac{B}{B_{0}}$.

Maximum growths for phytoplankton typically varies from 0.1 to $4 \mathrm{~d}^{-1}$, implying doubling times $\left(\frac{\ln 2}{\mu}\right)$ of a fraction of a day to one week. Figure $2.1 \mathrm{a}$ shows a typical example of exponential growth for maximum growth rates of 0.1 to $2 \mathrm{~d}^{-1}$. Exponential growth leads to rapid depletion of substrates and after some time, resources become limiting and phytoplankton enters into a stationary phase (Fig. 2.1b). Maximum growth size depends on phytoplankton group and size (Fig. 2.2; Box 2.1).
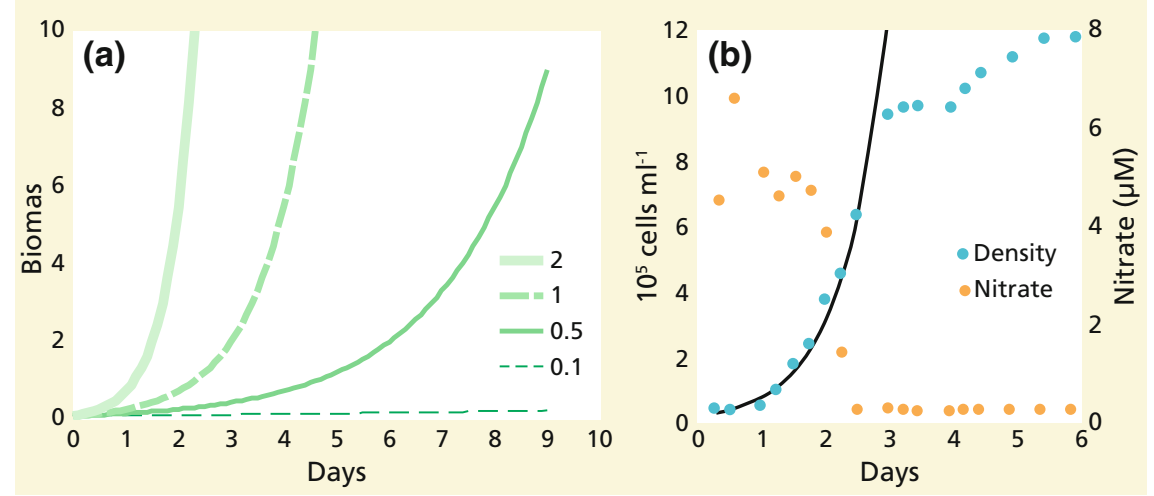

Fig. 2.1 a The increase in biomass during exponential growth with growth rates of $0.1,0.5,1$ and $2 \mathrm{~d}^{-1}$. b Cell growth of the diatom Thalassiosira pseudonana is exponential (growth rate of 1.4 $\mathrm{d}^{-1}$ ) till nitrate is depleted and then stationary growth occurs (Data from Davidson et al. 1999) 


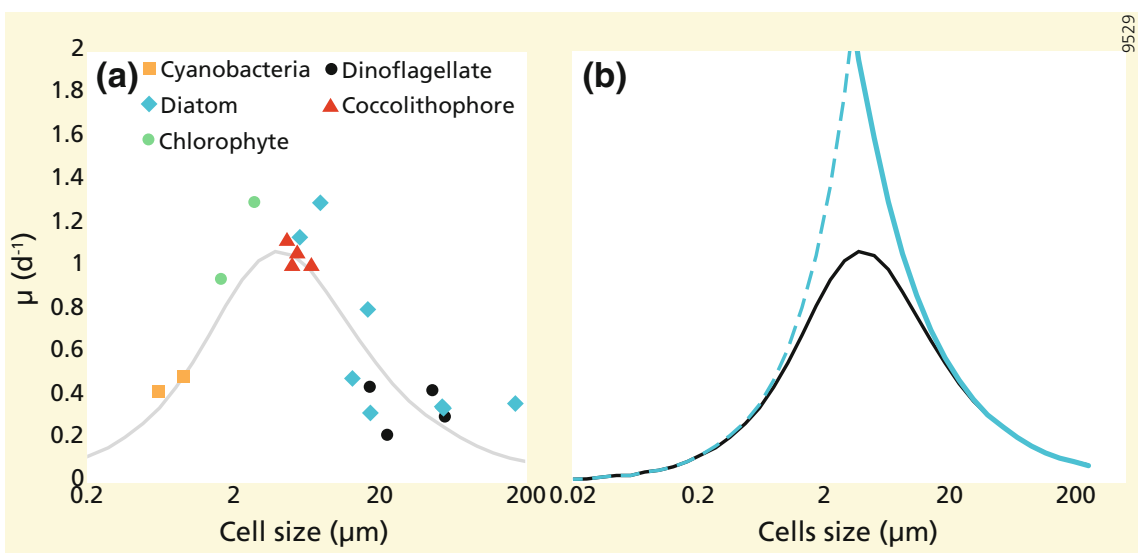

Fig. 2.2 a The relationship between growth rate and phytoplankton cell size and model prediction (grey curve) (Ward et al. 2017). b The relationship between growth rate and phytoplankton cell size (solid black line). Maximum nutrient uptake and requirement per cell scale positively with cell size (dashed blue line), while theoretical maximum growth rates scale negatively (solid blue line)

\subsubsection{Temperature Effect on Primary Production}

The temperature of a system provides a strong control on the functioning of organisms. Growth responses of populations to temperature are usually expressed by thermal tolerance curves, also known as reaction norms. Starting at low temperatures, growth initially increases linearly or exponentially up to a maximum $\mathrm{T}_{\text {opt }}$ and then typically declines relatively more rapidly: i.e. the response curve is often skewed to the left. In other words, phytoplankton growing near its optimum temperature is more sensitive to warming than to cooling (Fig. 2.3).

Although populations show distinct unimodal responses to temperature, mixed communities, and thus ecosystems, usually exhibit a smooth, monotonical increase best described by an exponential $\left(\mu=a e^{b T}\right.$, Fig. 2.4). The thermal response can then be described by

$$
\mu=a e^{b T}\left[1-\left(\frac{T-T_{\text {opt }}}{\text { width } / 2}\right)^{2}\right]
$$

where $a$ and $b$ are empirical parameters describing the maximum envelope for the mixed community and $T_{\text {opt }}$ and width describe the maximum growth rate and temperature range of individual populations. Eppley's (1972) seminal work on temperature and phytoplankton growth in the sea reported values of 0.59 for $a$ and 0.0633 for $b$. Note that this community response provides an upper limit for individual species and that high growth rates for individual species trade off with 


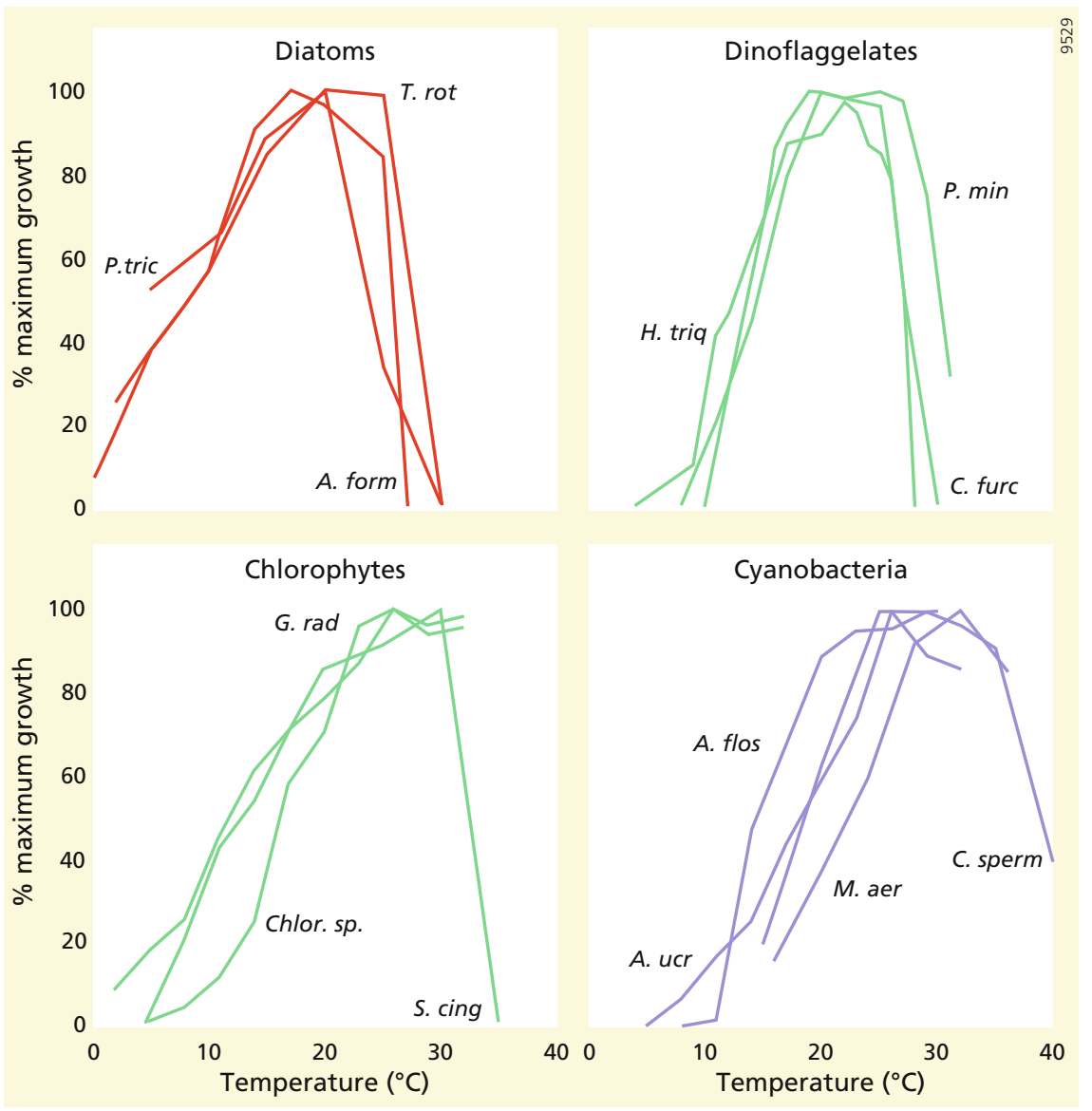

Fig. 2.3 Temperature response of the specific growth rates of three eukaryotic phytoplankton classes (Diatoms, Dinoflaggelates, Chlorophytes) and of Cyanobacteria from temperate freshwater and brackish environments (modified from Paerl et al. 2011). A. form = Asterionella Formosa, $T$. rot $=$ Thalassiosira rotula, $P$. tric $=$ Phaeodactylum tricornutum, $H$. triq $=$ Heterocapsa trique tra, $P . \quad$ min $=$ Prorocentrum minimum, $C$. furc $=$ Ceratium furcoides, $G . \quad$ rad $=$ Golenkinia radiate, Chlor. $s p .=$ Chlorella $s p ., \quad S . \quad$ cing $=$ Staurastrum cingulum, A. ucr $=$ Anabaena ucrainica, $\quad$ M. aer $=$ Microcystis aeruginosa,$\quad$ A. flos $=$ Aphanizomenon flos-aquae, $C$. sperm $=$ Cylindrospermopsis raciborskii

growth rates at other temperatures, with the consequence that species replace each other (Fig. 2.4).

This exponential temperature response of natural communities is usually expressed in terms of $\mathrm{Q}_{10}$ values or Activation energies $\mathrm{E}_{\mathrm{a}}$, both rooted in chemical thermodynamics (van 't Hoff and Arrhenius equations). The temperature $Q_{10}$ is normally defined as 


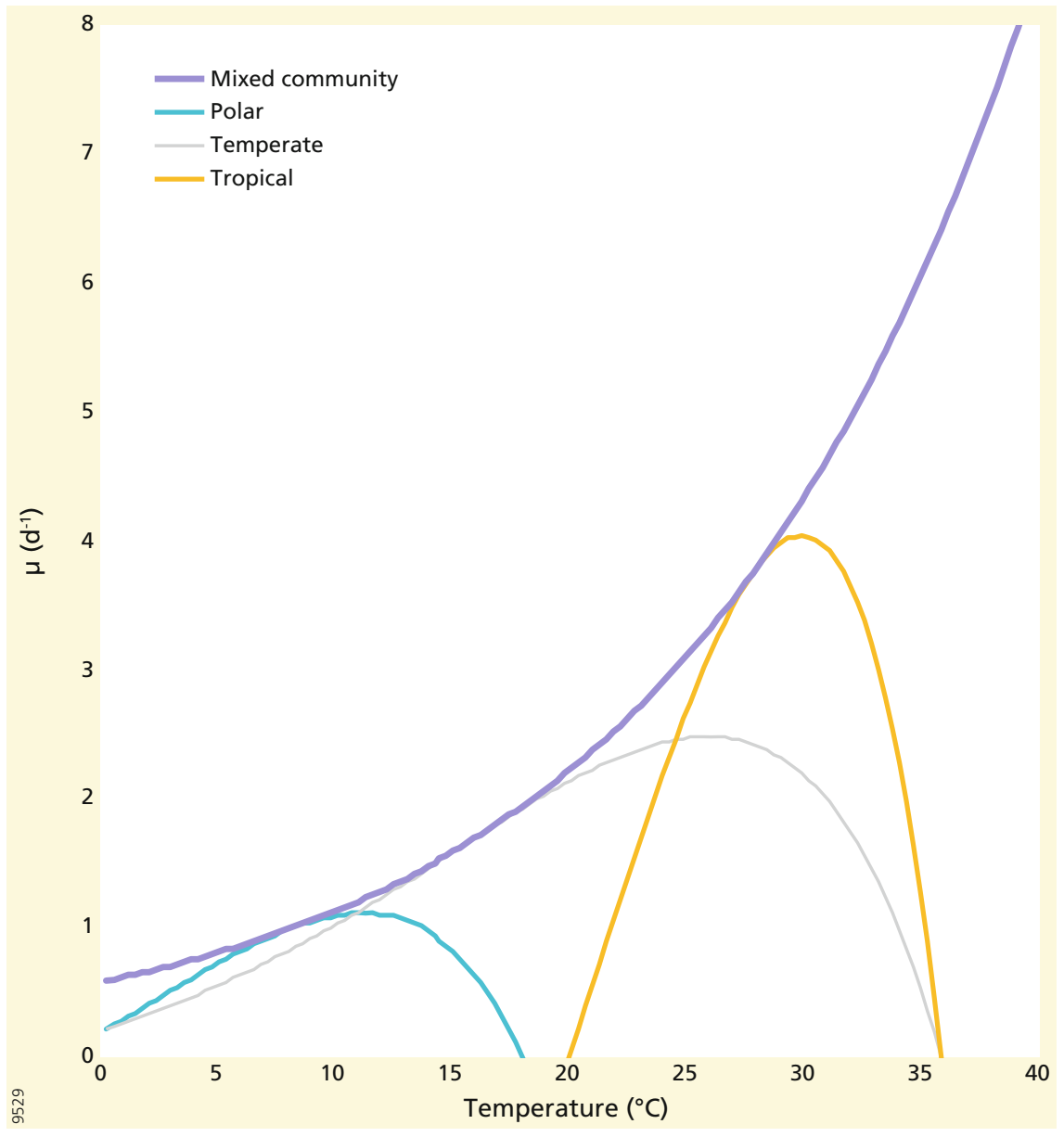

Fig. 2.4 Phytoplankton growth rate $\left(\mathrm{d}^{-1}\right)$ for a mixed community comprised of polar, temperate and tropical species. The mixed community response is based on Eppley (1972)

$$
Q_{10}=\left(\frac{\mu_{T}}{\mu_{R e f}}\right) e^{\left[\frac{10}{\left(T-T_{R e f}\right)}\right]}
$$

where $\mu_{\mathrm{T}}$ and $\mu_{\mathrm{Ref}}$ are the rate (e.g. growth) at temperature $\mathrm{T}$ and the reference temperature $\mathrm{T}_{\mathrm{Ref}}$ (Celsius). $\mathrm{Q}_{10}$ can be simplified to

$$
Q_{10}=\left(\frac{\mu_{R e f+10}}{\mu_{R e f}}\right)
$$

because it gives the rate increases for a $10{ }^{\circ} \mathrm{C}$ increase in $\mathrm{T}$ and is related to the parameter $\mathrm{b}$ of the exponential increase: $Q_{10}=e^{10 b}$. Eppley's curve thus 
corresponds to a $\mathrm{Q}_{10}$ of 1.88 . Typical $\mathrm{Q}_{10}$ values for biological processes are between 2 and 3 .

The Arrhenius equation is very similar and reads

$$
\mu=\mathrm{A} e^{\frac{-E_{a}}{R T}}
$$

where $\mathrm{A}$ is a pre-exponential factor $\left(\mathrm{time}^{-1}\right), \mathrm{E}_{\mathrm{a}}$ is the activation energy $\left(\mathrm{J} \mathrm{mol}^{-1}\right)$, $\mathrm{R}$ is the universal gas constant $\left(8.314 \mathrm{~J} \mathrm{~mol}^{-1} \mathrm{~K}^{-1}\right)$ and $\mathrm{T}$ is the absolute temperature (K). Sometimes the universal gas constant $\mathrm{R}$ is replaced by the Boltzman constant $\mathrm{k}\left(8.61710^{5} \mathrm{eV} \mathrm{K}^{-1}\right)$ and then $\mathrm{E}_{\mathrm{a}}$ is expressed in $\mathrm{eV}$ (energy per molecule) rather than $\mathrm{J} \mathrm{mol}^{-1}$. For the temperature range of seawater, $\mathrm{E}_{\mathrm{a}}$ and $\mathrm{Q}_{10}$ values are related via

$$
E_{a}=\frac{-R \ln Q_{10}}{\left(\frac{1}{T}-\frac{1}{T_{R e f}}\right)} \text { and } Q_{10}=e^{\left[\left(\frac{E_{a}}{R}\right) \frac{10}{\left(T \cdot T_{R e f}\right)}\right]},
$$

where $\mathrm{T}$ is again given in degrees Kelvin. Eppley's $\mathrm{Q}_{10}$ of 1.88 corresponds to activation energies of about $0.47 \mathrm{eV}$ or $45 \mathrm{~kJ} \mathrm{~mol}^{-1}$ at $20{ }^{\circ} \mathrm{C}$. One should realize that this is the optimal community temperature response, i.e. no other limiting factors. Apparent activation energies and $\mathrm{Q}_{10}$ values in the ocean are $\sim 0.30 \mathrm{eV}$ $\left(29 \mathrm{~kJ} \mathrm{~mol}^{-1}\right.$ ) and $\sim 1.5$, respectively, close to that of Rubisco (Edwards et al. 2016).

\subsubsection{Light}

Photosynthesis is a light dependent reaction, and light intensity has a major impact on growth rates. The relationship between photosynthesis and irradiance is normally presented as a $\mathrm{P}$ versus $\mathrm{E}$ curve, where $\mathrm{E}$ refers to radiant energy (mol quanta $\mathrm{m}^{2} \mathrm{~s}^{-1}$ ). Multiple equations have been presented to represent the photosynthesis to light relation, which differ in the number of parameters and whether or not they include the photo-inhibition effect at high light intensities or respiration of the autotroph. Photorespiration, the breakdown of photo-labile, intermediate carbon fixation products, is important in full-light exposed organisms, such as terrestrial plants, microphytobenthos and phytoplankton in the surface layer.

Common simple limitation functions are the hyperbolic, Monod model:

$$
f_{\text {lim }}(E)=\frac{E}{\left(E+K_{E}\right)}
$$

where $\mathrm{f}_{\lim }(\mathrm{E})$ is the light limitation function $\left(0<\mathrm{f}_{\lim }(\mathrm{E})<1\right), \quad \mathrm{K}_{\mathrm{E}}$ is a light-saturation parameter (typically $50-150 \mu \mathrm{mol}$ quanta $\mathrm{m}^{-2} \mathrm{~s}^{-1}$ for marine phytoplankton), and the Steele model (1962): 


$$
f_{\text {lim }}(E)=\frac{E}{E_{\max }} e^{\left(1-\frac{E}{E_{\text {Max }}}\right)}
$$

where $\mathrm{E}_{\max }$ is typically $50-300 \mu \mathrm{mol}$ quanta $\mathrm{m}^{-2} \mathrm{~s}^{-1}$ for marine phytoplankton (Soetaert and Herman 2009). The Steele model represents both the initial increase and the subsequent decrease due to photo-inhibition with only one parameter (Fig. 2.5).

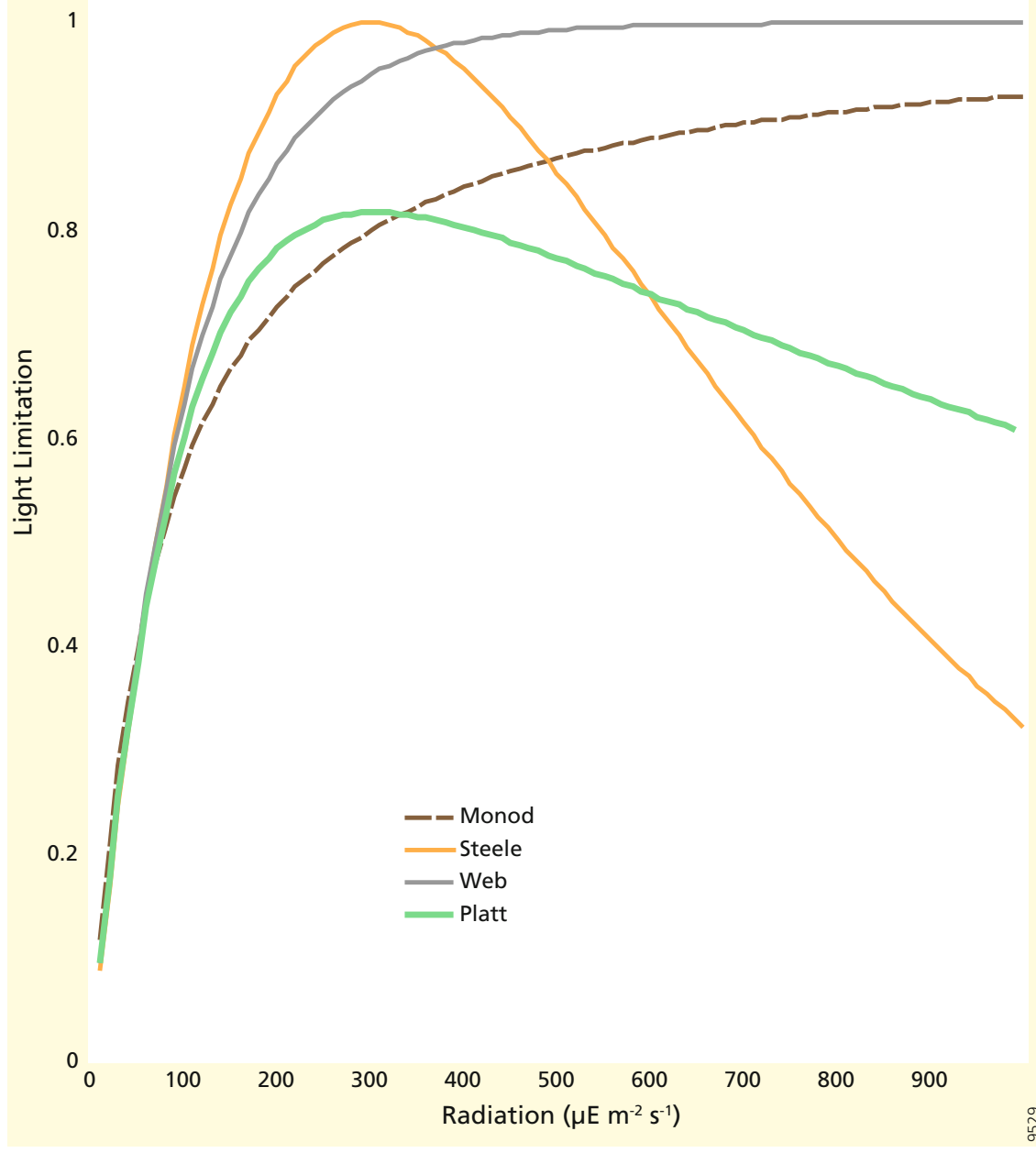

Fig. 2.5 Example of light inhibition functions in use. The Web and Monod models do not have light inhibition and only show different saturation behaviours, while the Steele and Platt models do incorporate the decrease in phytoplankton growth at high light levels, due to photo-inhibition 
The Webb et al. (1974) model is based on an exponential:

$$
f_{\text {lim }}(E)=1-\left[1-e^{\left(\frac{\alpha E}{P_{\max }}\right)}\right]
$$

where $\mathrm{P}_{\max }$ is the maximum rate at high light and $\alpha$ is the initial slope (increase in $\mathrm{P}$ with $\mathrm{E}$ at low light intensity). This equation ignores photo-inhibition. Alternatively, one can use the two-parameter Platt et al. (1980) equation:

$$
f_{\text {lim }}(E)=1-\left[1-e^{\left(\frac{\alpha E}{P_{\max }}\right)}\right]\left[e^{\left(\frac{-\beta E}{P_{\max }}\right)}\right]
$$

where is $\beta$ the intensity at the onset of photo-inhibition. Figure 2.5 illustrates the light limitation functions or PE curves presented above.

\subsubsection{Nutrient Limitation}

Growing phytoplankton needs a steady supply of resources to maintain growth. Nutrient uptake and growth kinetics are usually described using Monod or Droop kinetics. The former is the simpler model and normally used for steady-state conditions, while the Droop or internal quota model is preferred for transient conditions, e.g. in fluctuating environments. The equation for nutrient limitation following Monod kinetics is:

$$
\mu=\mu_{\max } \frac{S}{\left(S+K_{\mu}\right)} \text { or } f_{\text {lim }}(S)=\frac{S}{\left(S+K_{\mu}\right)},
$$

where $S$ is the substrate concentration of the medium water, $f_{\text {lim }}(S)$ is the nutrient limitation function, $\mu_{\max }$ is the maximal growth rate, and $\mathrm{K}_{\mu}$ is the half saturation constant for growth.

The Droop equation expresses growth rate as a function of the cellular quota (Q) of the limiting nutrient (Droop 1970):

$$
\mu=\mu_{\max }^{\prime} \frac{Q-Q_{\min }}{Q}
$$

where $\mathrm{Q}_{\min }$ is the minimum cellular quota for growth. Maximum growth rate on substrate $\left(\mu_{\max }\right)$ and cellular quota $\left(\mu_{\max }^{\prime}\right)$ are related via $\mu_{\max }=\mu_{\max }^{\prime} \frac{Q_{\max }-Q_{\min }}{Q_{\max }}$ where $\mathrm{Q}_{\max }$ is the maximum cellular quota if $\mathrm{S}$ increases. 


\subsection{From Theory and Axenic Mono-Cultures to Mixed Communities in the Field}

Progress in theory, creativity in experimental design, and dedicated hard laboratory work has generated process-based understanding of phytoplankton growth in the laboratory. This body of knowledge has deepened our understanding and guided our modelling efforts and field observation strategies, but we need to make many assumptions before we can apply this mechanistic approach to the field.

Let us return to our master Eq. (2.1): $\mathrm{P}=\mu \cdot \mathrm{B} \cdot \mathrm{f}_{\mathrm{lim}}$ (resources, environmental conditions). Ignoring environmental conditions, such as temperature, and substituting the simplest expressions introduced above we arrive at:

$$
P=\mu_{\max } \cdot B \cdot \frac{E}{\left(E+K_{E}\right)} \cdot \frac{S}{\left(S+K_{\mu}\right)}
$$

This equation for primary production contains 6 terms that need to be quantified for the case of a single limiting nutrient and a single phytoplankton species. The light availability (E) and nutrient concentration (S) display spatial and temporal gradients in nature, and the maximum growth rate $\mu_{\max }$ and half-saturation dependences $\left(\mathrm{K}_{\mathrm{E}}\right.$ and $\mathrm{K}_{\mu}$ ) require experimental or laboratory studies.

\subsubsection{Does Diversity Matter or Not?}

One of the most critical restrictions on the use of mechanistic complex models is related to phytoplankton diversity. Hutchinson (1961) identified the paradox that phytoplankton is highly diverse, despite the limited range of resources they compete for, in direct contrast to the competitive exclusion principle (Hardin 1960). Seawater typically contains tens of different species of primary producers, many for which there are no maximum growth data and known limitation functions. Accordingly, it is not feasible to simply apply Eq. 2.15 to individual species in the field and sum their contributions to obtain the primary production. Besides these theoretical arguments against the single species approach, there are also empirical reasons. Primary production and its dependence on environmental conditions (nutrients, temperature, light) are normally quantified at the community level in the absence of techniques to quantify species-specific primary production in natural waters. This discrepancy between, on the one hand, mechanistic, single-species approaches in the laboratory and, on the other hand, quantification of community responses and activities is somewhat unfortunate (Box 2.2). 


\subsubsection{Chl the Biomass Proxy}

The biomass of the primary producer $(\mathrm{B})$ is the second term in our master equation and quantifying this term in natural systems is more difficult than one initially would anticipate. Particulate organic carbon (POC) concentrations ( $\mathrm{g}$ C per unit volume) are a direct measure of phytoplankton biomass in laboratory settings with axenic cultures. However, in natural systems, the pool of particulate organic carbon comprises not only a mixture of phytoplankton species, each with its own maximum growth rate, temperature, light and nutrient dependence, but also a variable and sometimes dominating contribution of detritus (dead organic matter), bacteria and other heterotrophic organisms. It is for this reason that chlorophyll concentrations $(C h l)$ are used as a proxy for living primary producer biomass. The rationale is that $C h l$ is only produced by photosynthesizing organisms, degrades readily after death of the primary producers and can be measured relatively easily using a number of methods. Primary producer biomass (B) can then be calculated if one knows the $\mathrm{C}: C h l$ (or $C h l: \mathrm{C}$ ) ratio of the phytoplankton. However, this ratio differs among species and depends on growth conditions, in particular light and nutrient availability (Cloern et al. 1995). Chl:C ratios vary from $\sim 0.003$ to $\sim 0.055$ ( $\mathrm{gC} \mathrm{gChl}^{-1}$; Cloern et al. 1995), complicating going from phytoplankton growth to primary production. The very reason that $C h l$ is such a good proxy for photosynthesizing organisms is also the reason why it is not well suited to the task of partitioning itself among different phytoplankton species: it is in all primary producers harvesting light energy. Accessory and minor pigments such as zeaxanthine and fucoxanthine, do, however, have some potential to resolve differences among phytoplankton groups, but not at the species level.

\subsubsection{Light Distribution}

The distribution and intensity of photosynthetically active radiation in seawater is governed by the intensity at the sea surface $\left(\mathrm{E}_{0}\right)$ and scattering and absorption of light, with the result that light attenuates with depth. The decline of light intensity $\mathrm{E}$ with water depth $\mathrm{z}$ can be described by a simple differential equation, expressing that a constant fraction of radiation is lost:

$$
\frac{d E}{d z}=-k_{P A R} E
$$

where the proportionally constant $\mathrm{k}_{\mathrm{PAR}}$ is known as the extinction coefficient $\left(\mathrm{m}^{-1}\right)$. Solving this equation using the radiation at the seawater-air interface $\left(\mathrm{E}_{0}\right)$ yields the well-known Lambert-Beer equation:

$$
E=E_{0} e^{-k_{P A R} z}
$$


The extinction coefficient $\mathrm{k}_{\mathrm{PAR}}$ includes the absorption of radiation by water $\left(\mathrm{k}_{\mathrm{w}}\right)$, by the pigments from various primary producers $\left(\mathrm{k}_{\mathrm{Chl}}\right)$, by coloured dissolved organic matter $\left(\mathrm{k}_{\mathrm{DOC}}\right)$, and by suspended particulate material $\left(\mathrm{k}_{\mathrm{spm}}\right)$. The light extinction coefficient of pure water $\left(\mathrm{k}_{\mathrm{w}} \approx 0.015-0.035 \mathrm{~m}^{-1}\right)$ depends on the wave length of light, with longer wavelength (red) being adsorbed more strongly than shorter wavelengths (blue); this is the cause of the blue appearance of clear water. The other light extinction components have a different wavelength dependence: the attenuation coefficients of dissolved organic matter ( $\mathrm{k}_{\mathrm{DOC}}$; "gelbstoffe") and detritus $\left(\mathrm{k}_{\mathrm{SPM}}\right)$ increase with shorter wave length, while that of phytoplankton $\left(\mathrm{k}_{\mathrm{Chl}}\right)$ varies depending on the species, i.e. the pigment composition of the primary producers (Kirk 1992; Falkowski and Raven 1997).

Oceanographers often divide ocean waters into two classes with respect to light

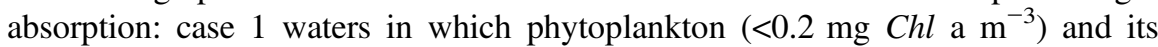
debris add only to $\mathrm{k}_{\mathrm{w}}$, and case 2 waters which have high pigment concentration and light attenuation because of (terrestrially derived) dissolved organic carbon and suspended particulate waters. The overall light attenuation $\left(\mathrm{k}_{\mathrm{PAR}}\right)$ in case 1 waters can be approximated by (Morel 1988):

$$
k_{P A R}=0.121 \times C h l^{0.428}
$$

where $C h l$ is in $\mathrm{mg} \mathrm{Chl} \mathrm{a} \mathrm{m}^{-3}$.

Other useful empirical relations link light attenuation $\left(\mathrm{k}_{\mathrm{PAR}}\right)$ to the Secchi depth $\left(\mathrm{z}_{\mathrm{Sec}}, \mathrm{m}\right)$, the depth at which a white disk disappears visually:

$$
k_{P A R}=\frac{q}{z_{S e c}},
$$

where q varies from 1.7 in case 1 waters to 1.4 in case 2 waters (Gattuso et al. 2006) and

$$
k_{P A R}=0.4+\frac{1.09}{z_{S e c}}
$$

for turbid estuarine waters (Cole and Cloern 1987).

Light attenuation coefficients vary from $0.02 \mathrm{~m}^{-1}$ in oligotrophic waters, $0.5 \mathrm{~m}^{-1}$ in coastal waters, and to $>2 \mathrm{~m}^{-1}$ in turbid waters Light attenuation by water and phytoplankton dominate in the open ocean and on the shelf. In other coastal waters, including estuaries, phytoplankton and suspended particles dominate light attenuation, while light attenuation is primarily due to suspended particles in more turbid systems (Heip et al. 1995).

The light attenuation governs the euphotic zone depth $\left(\mathrm{z}_{\mathrm{eu}}, \mathrm{m}\right)$, i.e., the depth where radiation is $1 \%$ of the incoming:

$$
\ln 0.01=-k_{P A R} z_{E U} \text { or } z_{E U}=\frac{4.6}{k_{P A R}}
$$




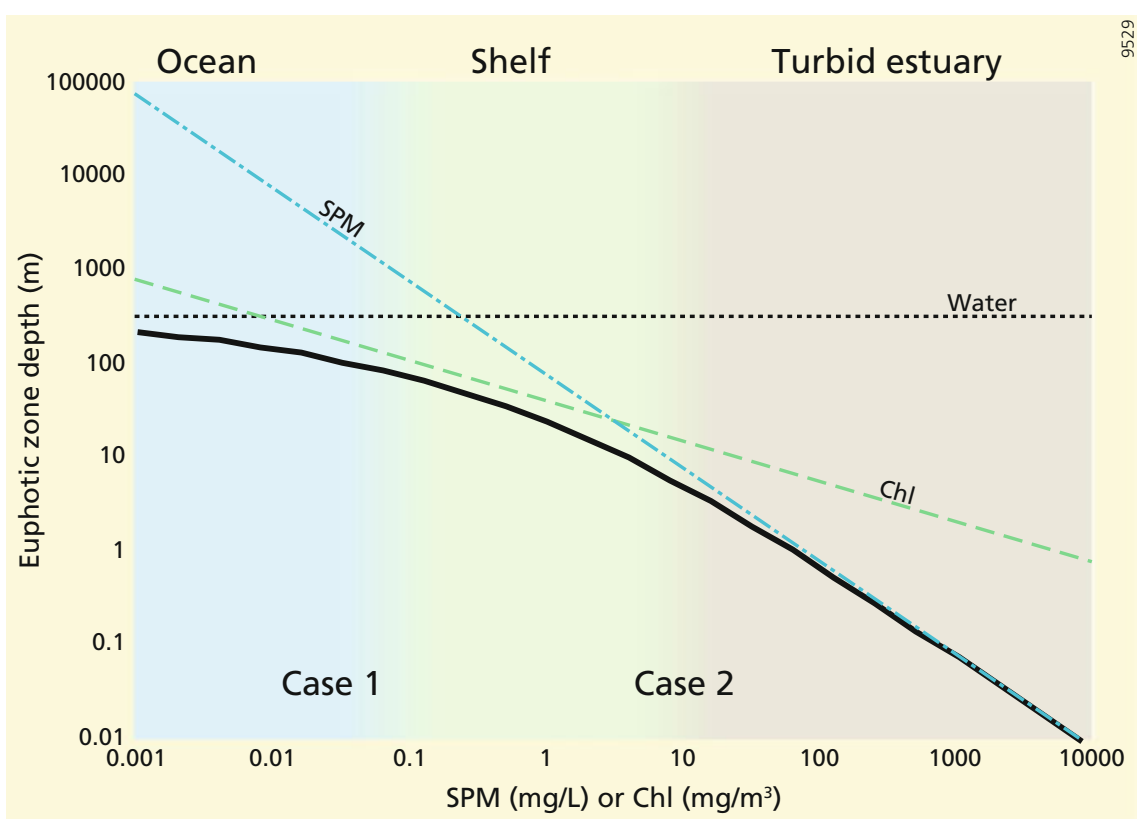

Fig. 2.6 Conceptual figure of euphotic zone depth (solid black line) as a function of suspended particulate matter (SPM, $\left.\mathrm{mg} \mathrm{L}^{-1}\right)$ and phytoplankton concentrations $\left(C h l, \mathrm{mg} \mathrm{m}^{-3}\right.$ ). The euphotic zone is more $>200 \mathrm{~m}$ in the clearest ocean water with very low phytoplankton and light attenuation by water itself dominates. In most of the ocean, phytoplankton dominates light attenuation and euphotic zone depth scales with phytoplankton concentration. In estuaries and other turbid systems, dissolved organic matter and in particular suspended particles attenuate light and the euphotic zone narrows to less than one meter. Coastal systems and eutrophic parts of the ocean are in between. Case 1 and 2 oceanic waters are indicated. Light attenuation due to phytoplankton was modelled following Morel (1988; Eq. 2.18), while that due to suspended particles followed Cloern (1987) and euphotic depth was calculated as $4.6 / \mathrm{k}_{\mathrm{PAR}}$

The euphotic zone is a key depth horizon in aquatic sciences because photosynthesis is largely limited to this zone. Moreover, the bottom of the euphotic zone is often used as reference for export of organic matter. Euphotic zone depths vary from about $200 \mathrm{~m}$ in the oligotrophic ocean, to tens of meters in shelf systems, to meters in coastal waters and a few decimetres in turbid and/or eutrophic estuaries (Fig. 2.6).

\subsection{Factors Governing Primary Production}

Having presented the factors governing phytoplankton production in laboratory studies and the limitations in applying that knowledge to natural systems, we have all the ingredients to explore the factors governing the (depth) distribution and rate of primary production in natural ecosystems. 


\subsubsection{Depth Distribution of Primary Production}

Consider a system with a light profile following the Lambert-Beer equation (2.17) with $\mathrm{E}_{\mathrm{o}}=10 \mathrm{~mol} \mathrm{~m} \mathrm{~m}^{-2}$ and $\mathrm{k}_{\mathrm{PAR}}=0.1 \mathrm{~m}^{-1}$ (corresponding to a euphotic zone of $46 \mathrm{~m}$ ) and a nutrient pattern as shown in Fig. 2.7. Nutrients are low in the upper $25 \mathrm{~m}\left(\mathrm{~N}=0.1 \mu \mathrm{mol} \mathrm{m}{ }^{-3}\right)$ and then exponentially increase with a depth coefficient $0.1 \mathrm{~m}^{-1}$ to a maximum of $10 \mu \mathrm{mol} \mathrm{m} \mathrm{m}^{-3}$.

If we further assume (1) that physical mixing homogenizes phytoplankton biomass ( $\mathrm{B}=$ constant), (2) that there is only one limiting nutrients $(\mathrm{N})$, and (3) that light and nutrient limitations can be described by Monod relations with parameter $\mathrm{K}_{\mathrm{E}}$ and $\mathrm{K}_{\mathrm{N}}$. This allows combining $\mu_{\max }$ and $\mathrm{B}$ into a depth independent maximal production $\mathrm{P}_{\mathrm{m}}$. The modelled $\mathrm{P}$ is then:

$$
P=P_{m} \frac{E}{\left(E+K_{E}\right)} \cdot \frac{N}{\left(N+K_{N}\right)}
$$

Taking $\mathrm{K}_{\mathrm{N}}$ and $\mathrm{K}_{\mathrm{E}}$ values of 1, i.e. $10 \%$ of $\mathrm{E}_{\mathrm{o}}$ and maximum $\mathrm{N}$ at depth, and combining Eq. 2.22 with the light and nutrient profiles, we can then calculate the primary production as a function of depth (Fig. 2.7, green curve). Although these light and nutrient profiles and the model parameters $\mathrm{K}_{\mathrm{N}}$ and $\mathrm{K}_{\mathrm{E}}$ numbers have been chosen arbitrarily, they are reasonable and generate a representative depth profile for primary production with a subsurface maximum, as observed as a deep chlorophyll maximum (Fig. 2.8). In the upper $25 \mathrm{~m}$, primary production is rather low because of nutrient limitation and declines slightly with depth because of light attenuation (Fig. 2.7). Primary production is optimal at depths between 25 and $40 \mathrm{~m}$, i.e. where the nutricline and the lower part of the euphotic zone overlap. Primary production below $25 \mathrm{~m}$ is primarily light-limited, but accounts for about $75 \%$ of the depth-integrated primary production. Increasing surface-water nutrient concentrations or the phytoplankton affinity for nutrients (lowering $\mathrm{K}_{\mathrm{N}}$ ) would increase primary production in the top $25 \mathrm{~m}$, but not so much at depth (Fig. 2.9a). Increasing the photosynthetic performance at low light levels (lowering $\mathrm{K}_{\mathrm{E}}$ ) would increase primary production at depth (Fig. 2.9b). Phytoplankton living in the surface ocean can thus optimize their performance by investing in nutrient acquisition, while those living in the subsurface would best optimize their light harvesting organs. This simple model explains why deep chlorophyll maxima occur in low-nutrient systems and why the depth distribution of primary production follows light in eutrophic systems (e.g. during early spring in Bermuda Atlantic station, Fig. 2.8).

\subsubsection{Depth-Integrated Production}

The overall control of light on depth-integrated production underlies satellite-derived algorithms for primary production and coastal predictive equations. For ecosystem and biogeochemical studies, the focus is on net primary production, i.e. carbon fixation minus phytoplankton respiration, expressed per $\mathrm{m}^{2}$ and unit time 


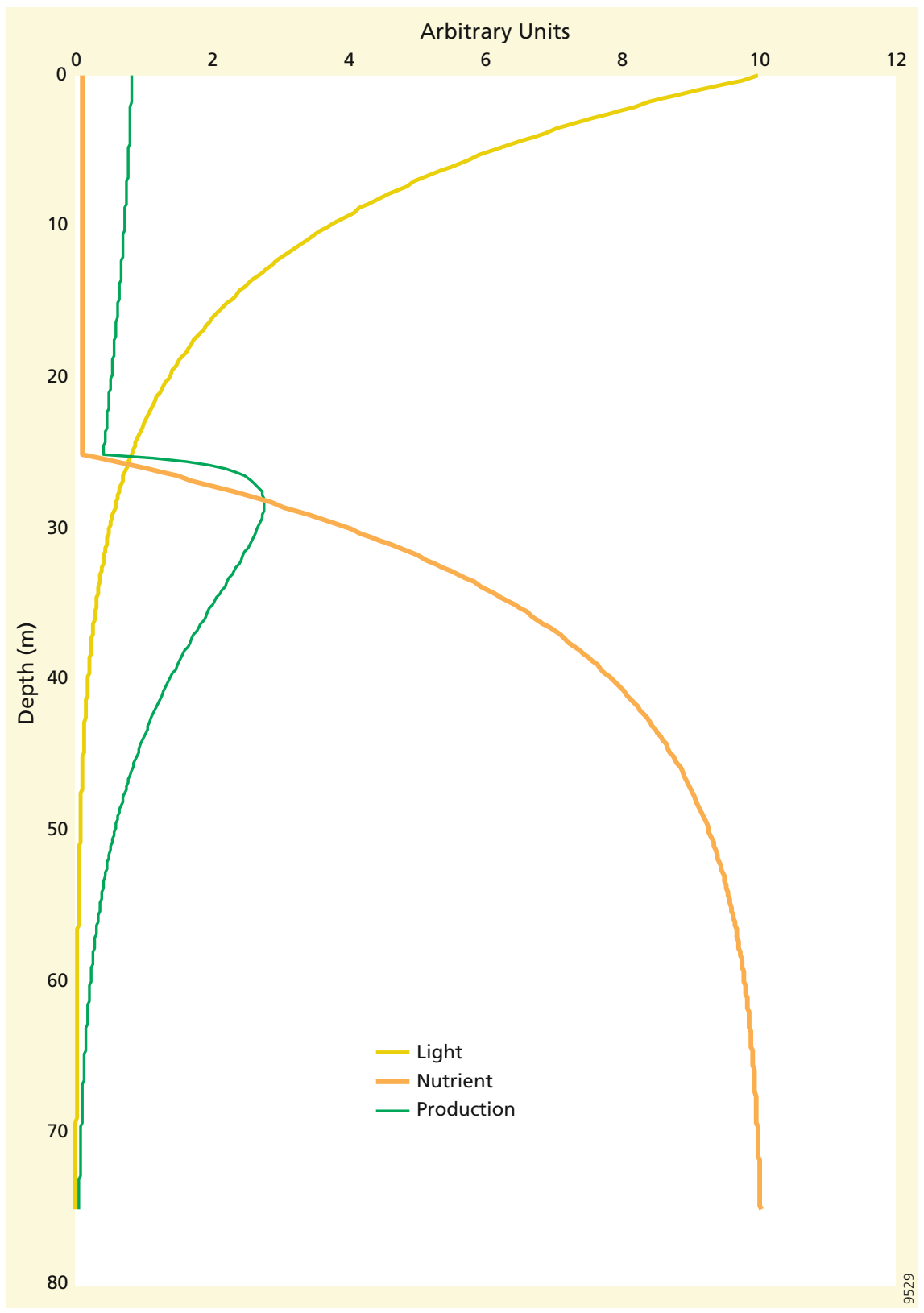

Fig. 2.7 Light and nutrient distribution versus depth and resulting primary production. The subsurface maximum often results in a deep chlorophyll maximum 


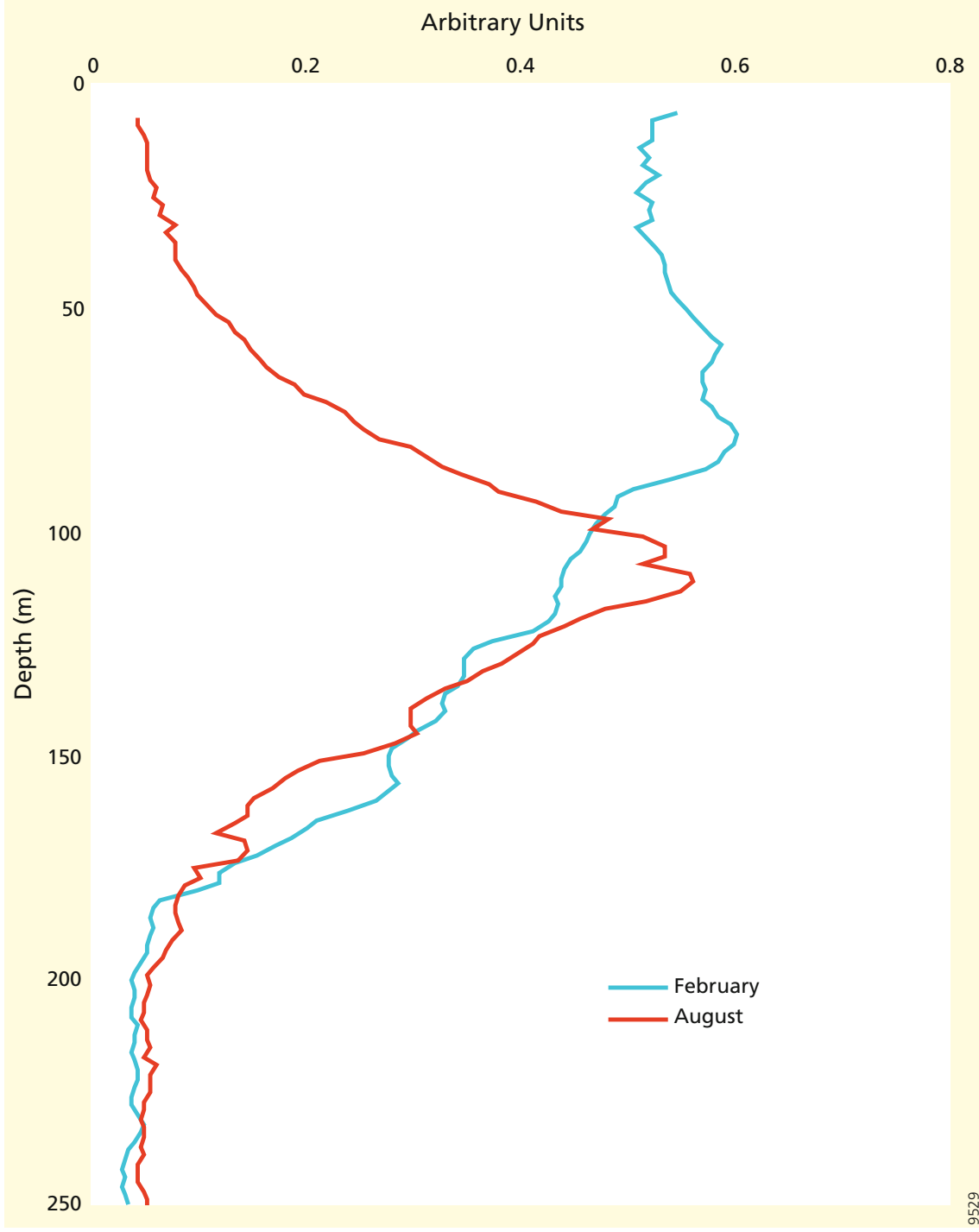

Fig. 2.8 Fluorescence data at station BATS (Bermuda Atlantic Time Series) in February and August 1996

(day, year). Behrenfeld and Falkowski (1997) showed that depth-integrated net primary production $\left(\mathrm{P}, \mathrm{g} \mathrm{C} \mathrm{m}^{-2} \mathrm{yr}^{-1}\right)$ can be estimated as:

$$
P=P_{\text {opt }} \times C h l \times z_{e u} \times D L \times f_{\text {lim }}(E)
$$




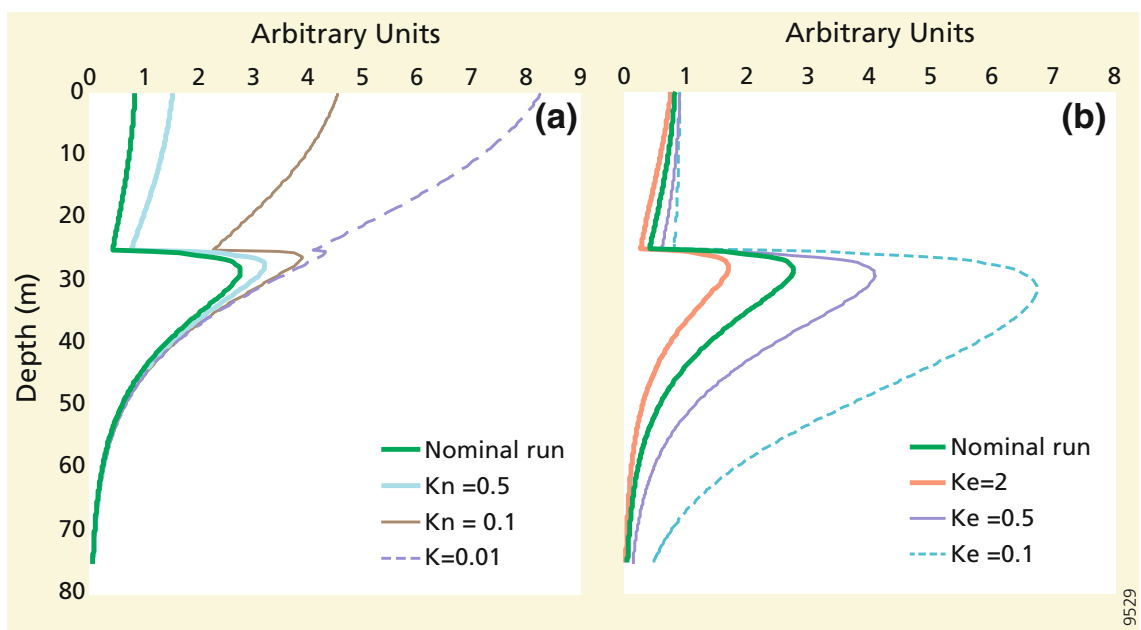

Fig. 2.9 a The impact of nutrient availability on the vertical distribution of primary production. Low half-saturation constants $\mathrm{K}_{\mathrm{N}}$ imply high availability of nutrient for phytoplankton. b The impact of light harvesting efficiency on primary production. A high affinity (low $\mathrm{K}_{\mathrm{E}}$ ) for light causes higher primary production at depth. The nominal run is presented in Fig. 2.7

where $\mathrm{P}_{\mathrm{opt}}$ is the maximum daily photosynthesis rate $\left(\mathrm{mg} \mathrm{C}(\mathrm{mgChl})^{-1} \mathrm{~h}^{-1}\right), \mathrm{z}_{\mathrm{eu}}$ is the euphotic zone depth, DL is day length $(h)$, and $f_{\text {lim }}(E)$ is a light limitation function. The similarity with our master Eq. (2.1) is evident, when nutrient limitation and environmental conditions are ignored. Integrating (Eq. 2.1) with depth to $\mathrm{Z}_{\mathrm{EU}}$, and with time to sunset, we arrive at:

$$
P=\int_{0}^{z_{E U}} \int_{\text {sunrise }}^{\text {sunset }} \mu_{\max } \cdot B \cdot f_{\text {lim }}(E)
$$

which is identical to (2.23), with $\mathrm{P}_{\mathrm{opt}}=\mu_{\max } ; C h l=\mathrm{B}, \quad \int_{0}^{z_{E U}}=\mathrm{z}_{\mathrm{eu}}$, and $\int_{\text {sunsise }}^{\text {sunset }}=\mathrm{DL}$.

Behrenfeld and Falkowski (1997) showed that $85 \%$ of the variance in global net primary production can be attributed to depth integrated biomass $\left(C h l \times \mathrm{z}_{\mathrm{eu}}\right)$ and the maximal photosynthesis parameter $\mathrm{P}_{\mathrm{opt}}$, with other factors, such as differences in light limitation functions, depth distributions of phytoplankton biomass and day length (DL), being less important. Consequently, the most rudimentary model would be (Falkowski 1981):

$$
P=\psi \times C h l \times z_{E U} \times E_{o}
$$

stating that net primary production $(\mathrm{P})$ scales linearly with depth integrated biomass $\left(C h l \times \mathrm{z}_{\mathrm{EU}}\right)$, incoming radiation $\left(\mathrm{E}_{\mathrm{o}}\right)$ and an optimal photosynthetic parameter $(\psi)$. Similar semi-empirical relations are often used in estuaries (Cole and Cloern 1987; Heip et al. 1995):

$$
P=a+b\left(C h l \times z_{E U} \times E_{0}\right)
$$

where $\mathrm{a}$ and $\mathrm{b}$ are regression coefficients that are system specific. 


\subsubsection{Critical Depths}

The overall governing role of light on primary production and phytoplankton dynamics also underlies the use of two critical depth horizons, often credited to Sverdrup (1953): the compensation depth $\left(\mathrm{z}_{\mathrm{c}}\right)$ and critical depth $\left(\mathrm{z}_{\mathrm{cr}}\right)$. These were introduced to understand and predict spring blooms in the ocean. At the compensation depth $\left(\mathrm{z}_{\mathrm{c}}\right)$, phytoplankton photosynthesis is balanced by community respiration (Fig. 2.10), i.e. the depth of the radiation level at which photosynthesis (by phytoplankton) compensates their respiration $\left(\mathrm{E}_{\mathrm{c}}\right)$. This compensation depth should not be confused with the physics governed mixed-layer depth $\left(\mathrm{z}_{\mathrm{mld}}\right)$ and the critical depth $\left(\mathrm{z}_{\mathrm{cr}}\right)$, where primary production integrated through the water column and over the day will equal the daily water column integrated community losses of carbon (Sverdrup 1953; Fig. 2.10). These depths are pivotal to the formation of

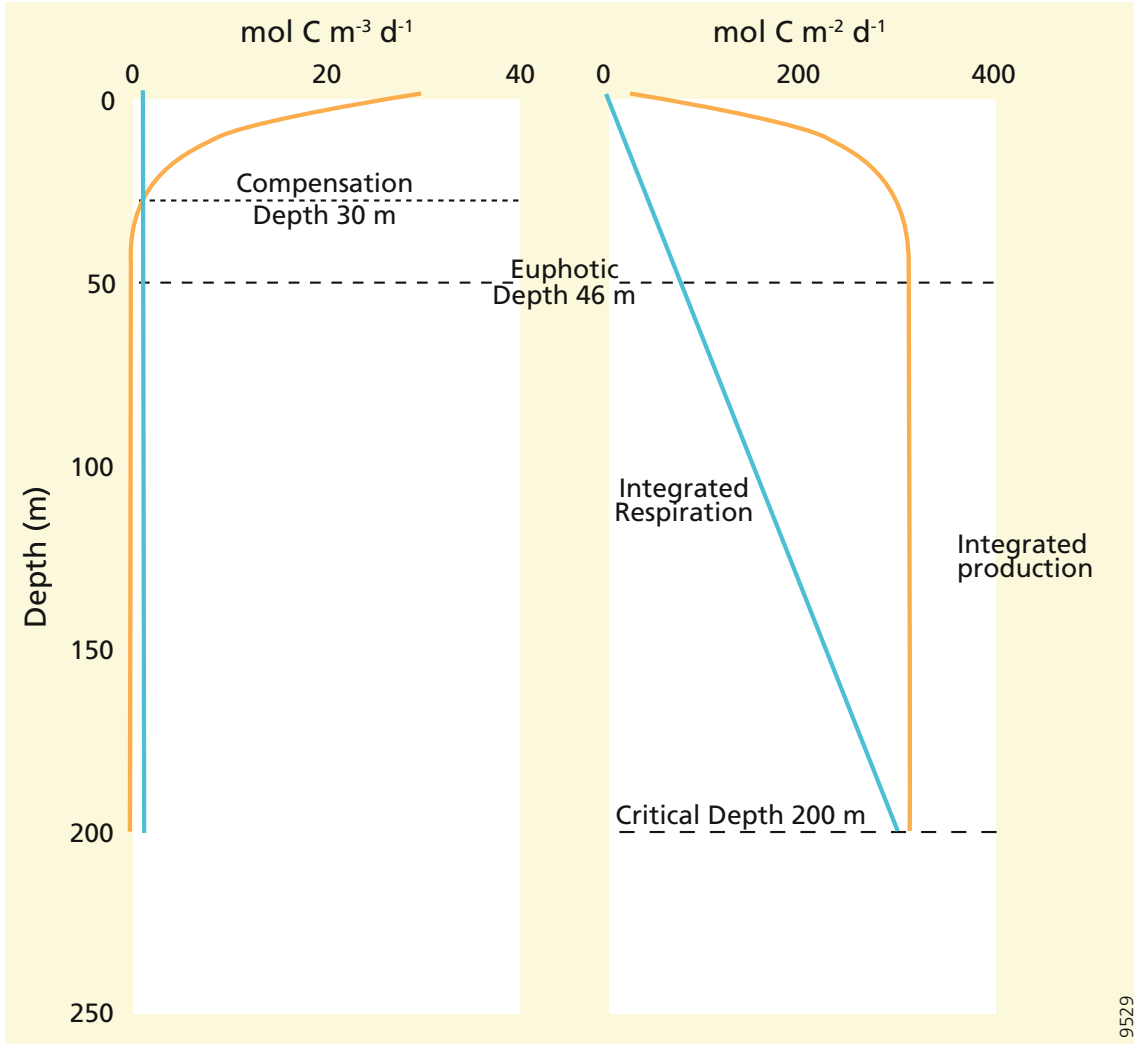

Fig. 2.10 Production and respiration (left) and depth integrated production and respiration (right) as a function of water depth. The critical depth is where depth integrated production and respiration balance $(200 \mathrm{~m})$, the compensation depth is where production and respiration of phytoplankton balance $(30 \mathrm{~m})$. The euphotic zone is governed only by light attenuation and is $46 \mathrm{~m} . \mathrm{P}_{0}$ is $30 \mathrm{~mol} \mathrm{~m} \mathrm{~d}^{-1} ; \mathrm{R}_{0}$ is $0.05^{*} \mathrm{P}_{0} ; \mathrm{E}_{0}=30 \mathrm{~mol} \mathrm{~m} \mathrm{~m}^{-2} \mathrm{~d}^{-1} \mathrm{k}_{\mathrm{PAR}}=0.1 \mathrm{~m}^{-1}$ 
phytoplankton blooms in the oceans (Sverdrup 1953). If the mixed layer is deeper than the critical depth $\left(\mathrm{z}_{\mathrm{cr}}\right)$, then phytoplankton will spend relatively too much time at low irradiances and carbon losses are not compensated by sufficient growth. Conversely, if the mixed layer is shallower than $\mathrm{z}_{\mathrm{cr}}$, phytoplankton communities can grow and blooms can develop. Assuming that carbon losses $\left(\mathrm{R}_{\mathrm{o}}\right)$ are constant with depth, there is no nutrient limitation, and gross primary production is linearly related to radiation, which in turn depends exponentially on depth (Eq. 2.18), primary production is described by:

$P=P_{0} e^{-k_{P A R} z}$, where $\mathrm{P}_{0}$ is the surface productivity. One eventually arrives at following relations for Sverdrup's critical depth, $\mathrm{z}_{\mathrm{cr}}$ :

$$
\frac{\left(1-e^{k_{P A R} z_{c r}}\right)}{k_{P A R} z_{c r}}=\frac{E_{C}}{E_{0}}=\frac{R_{0}}{P_{0}}
$$

where $E_{c}$ is the radiation level at the compensation depth and $R_{o}$ is the depth-independent community respiration rate (Sverdrup 1953; Siegel et al. 2002). Clearly, light attenuation is a major factor, not only governing $z_{\mathrm{eu}}$, but also $\mathrm{z}_{\mathrm{c}}$ and $\mathrm{z}_{\mathrm{cr}}$. The critical depth $\left(\mathrm{z}_{\mathrm{cr}}\right)$ is usually 4 to 7 times higher than the euphotic zone depth $\left(\mathrm{z}_{\mathrm{eu}}\right)$. The compensation depth $\left(\mathrm{z}_{\mathrm{c}}\right)$ is typically $50-75 \%$ of the euphotic zone depth (Siegel et al. 2002; Sarmiento and Gruber 2006; Fig. 2.10). For simplicity, the compensation depth is often taken equal to the euphotic zone depth; this should be discouraged, because it implies that community respiration represents only $1 \%$ of maximal production. The depth of the euphotic zone $\left(\mathrm{z}_{\mathrm{EU}}\right)$ is an optical depth governed by the light attenuation and thus only indirectly impacted by phytoplankton via their effect on $\mathrm{k}_{\mathrm{PAR}}$, while the compensation depth depends on the community structure (algal physiology and heterotrophic community). The Sverdrup critical depth model is simple, instructive and predictive: it can explain bloom initiation when mixed layers shallow and link it to physical sensible and quantifiable parameters. However, it is sometimes difficult to apply because of inconsistencies and uncertainties in the parameterisation (phytoplankton vs. community respiration and other phytoplankton losses) and the validity of the assumptions (no nutrient limitation, well-mixed layer).

The critical depth horizon concept has been developed for deep waters, but a similar approach can be applied to shallow ecosystems. In shallow coastal systems, it is the relative importance of water depth and euphotic zone depth that governs (a) where production occurs and (b) whether phytoplankton biomass will increase or not. If water depth is less than the euphotic depth $\left(\mathrm{z}_{\mathrm{EU}}\right)$ light reaches the seafloor and primary production by microbial photoautotrophs (microphytobenthos), as well as macroalgae and seagrasses, may occur. Gattuso et al. (2006) showed that this may happen over about $1 / 3$ of the global coastal ocean. If water depth exceeds the euphotic zone by more than a factor 4-7 then phytoplankton losses in the dark cannot be compensated fully by photosynthesis and phytoplankton communities will lose biomass (Cloern 1987; Heip et al. 1995). Vice versa, if water depth <4-7 times $\mathrm{Z}_{\mathrm{EU}}$ phytoplankton growth is maintained. Consequently, shallowing of ecosystems (e.g. water flowing over a tidal flat or development of stratification) 
Fig. 2.11 Conceptual picture of phytoplankton bloom in estuarine plume

\section{Low Light \\ High Nutrient}

High Light

Low Nutrient

stimulates phytoplankton community growth, all other factors remaining equal, while deepening of water bodies will cause a decline. Moreover, in turbid systems where the light attenuation $\left(\mathrm{k}_{\mathrm{PAR}}\right.$ ), and thus $\mathrm{z}_{\mathrm{EU}}$ (Fig. 2.7), are governed by suspended particulate matter dynamics, phytoplankton communities may experience variable twilight conditions and have difficulty maintaining positive growth. Consequently, when turbid rivers and estuarine waters with high nutrients reach the sea, particles settle and light climate improves, phytoplankton blooms may develop and utilize the nutrients (Fig. 2.11).

Sverdrup's critical depth hypothesis is based on the assumption that phytoplankton biomass and phytoplankton losses are homogenously distributed in the mixed layer. However, the mixed layer with uniform temperature as used in Sverdrup's approach does not match with the layer of turbulent mixing in the ocean (Franks 2015). It is more realistic to represent phytoplankton biomass (B) as governed by the balance between production, respiration losses and transport by eddy diffusion and particle settling. Again, we assume gross primary production is linearly related to radiation (which declines exponentially); hence: $P=P_{0} e^{-k_{P A R} z}$. Phytoplankton respiration loss is considered a first order process: Loss $=r B$ with a first-order rate constant (r). Under the assumption of steady-state we then arrive at (see Box 1.1):

$$
K_{z} \frac{d^{2} B}{d z^{2}}-w \frac{d B}{d z}-r B=P_{0} e^{-k_{P A R} z}
$$


where $K_{z}$ is the vertical eddy diffusion coefficient $\left(\mathrm{m}^{2} \mathrm{~s}^{-1}\right)$, w is the settling velocity ( $\mathrm{m} \mathrm{s}^{-1}$; positive downwards), the other terms have been defined before. Considering a semi-infinite domain, i.e. $\frac{d B}{d x}=0$ at large depth, and phytoplankton biomass $\mathrm{B}_{0}$ at the water-air interface, we obtain the following solution:

$$
B=\left(B_{0}-\frac{P_{0}}{K_{z} k_{P A R}^{2}+w k_{P A R}-r}\right) e^{\alpha z}+\frac{P_{0}}{K_{z} k_{P A R}^{2}+w k_{P A R}-r} e^{-k_{P A R} z}
$$

with $\alpha=\frac{w-\sqrt{w^{2}+4 r K_{z}}}{2 K_{z}}$.

The second exponential term accounts for light-dependent production, while the first exponential comprises water-column mixing, phytoplankton settling, and phytoplankton losses. To simplify matters, we assume that phytoplankton biomass is zero at the air-water interface. The first and second term then balance if $\frac{w-\sqrt{w^{2}+4 r K_{z}}}{2 K_{z}}=-k_{P A R}$. After re-arrangement to isolate the eddy diffusion coefficient, we obtain

$$
K_{z}=\frac{r-k_{P A R} w}{k_{P A R}^{2}}
$$

In other words, the vertical eddy diffusion coefficient $\mathrm{K}_{\mathrm{z}}$ should be less than $\frac{r-k_{P A R} w}{k_{P A R}^{2}}$ for positive values of phytoplankton biomass (B).

Huisman et al. (1999) presented a more elaborate model on phytoplankton growth in a turbulent environment, including a feedback between phytoplankton biomass and $\mathrm{k}_{\mathrm{PAR}}$. Through scaling and numerical analysis of a model without phytoplankton sinking $(\mathrm{w}=0)$, they derived a relationship between the maximum turbulent mixing coefficient $\mathrm{K}_{\mathrm{z}}$ and $\mathrm{k}_{\mathrm{PAR}}: K_{z}=\frac{0.31}{k_{P A R}^{2}}$. If we also ignore phytoplankton advection ( $\mathrm{w}=0$ in Eq. 2.30), $K_{z}<\frac{r}{k_{P A R}^{2}}$, fully consistent with Huisman et al. (1999). The critical turbulence level for phytoplankton growth is thus inversely related to the square of the attenuation of light. Moreover, the phytoplankton loss is the scaling factor. For turbid systems such as estuaries and other coastal systems with high light attenuation $\left(\mathrm{k}_{\mathrm{PAR}}\right)$, turbulent mixing should be minimal to allow net growth, consistent with observations by Cloern (1991) that phytoplankton blooms develop during neap tide when turbulent mixing intensity is lowest. Conversely, in clear, oligotrophic waters, light attenuation is limited and phytoplankton blooms can occur at relatively high mixing rates. Sinking phytoplankton $(\mathrm{w}>0$ ) will lower the numerator of Eq. 2.30 and thus lower the critical turbulence levels, while buoyant phytoplankton $(\mathrm{w}<0)$ will increase the maximal allowable turbulence, and thus the scope for phytoplankton growth. 


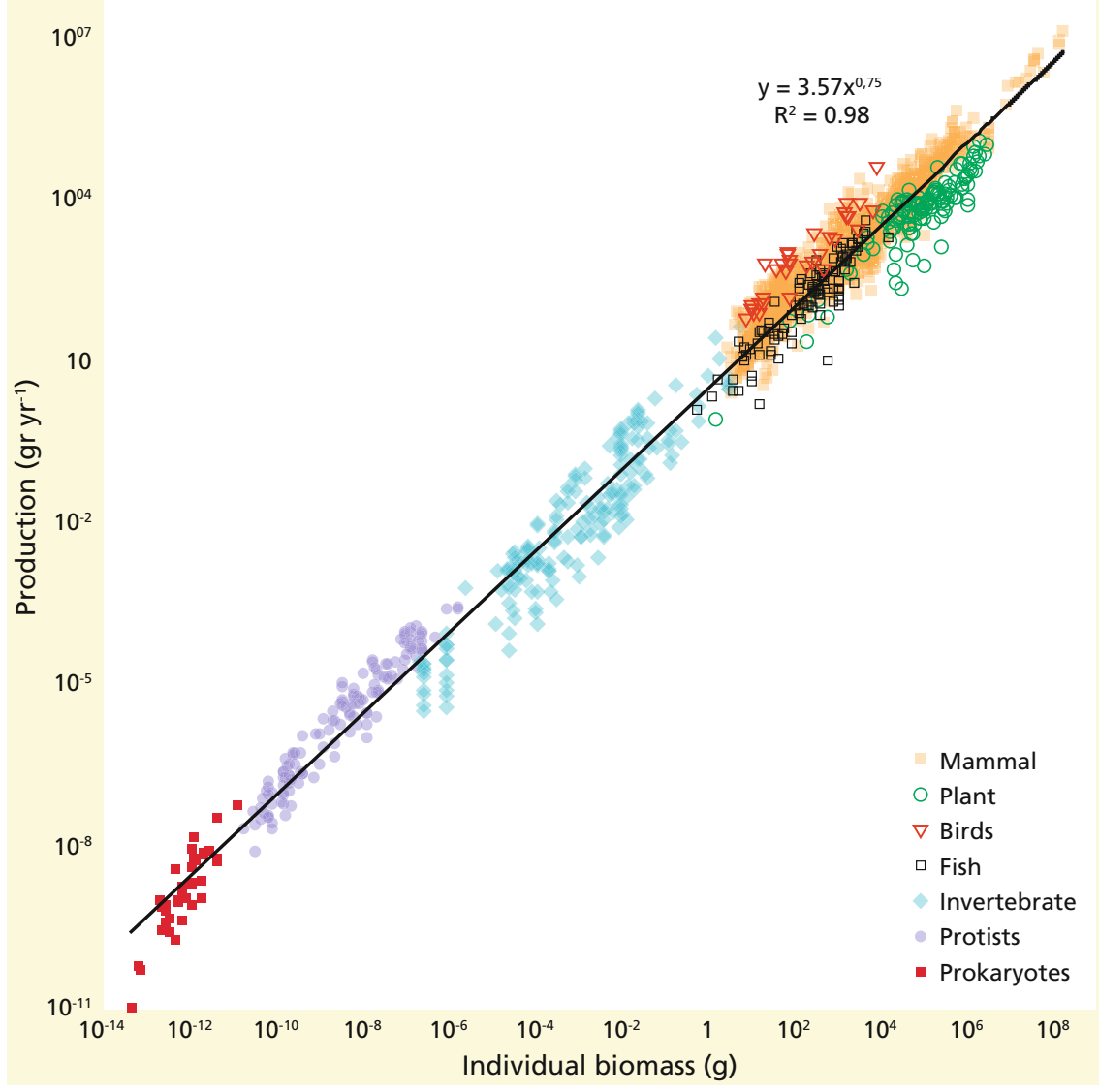

Fig. 2.12 Production as a function of individual biomass for a wide variety of organisms, including animals, plants and prokaryotes (based on data compiled by Hatton et al. (2015))

\section{Box 2.1: Phytoplankton size based traits}

The intrinsic maximum growth of phytoplankton varies with size (Fig. 2.2). Metabolic activity of organisms usually scales with size and when expressed in terms of mass or volume $(\mathrm{V})$ follows a simple power law

$$
\mu=a V^{b}
$$

where $b=-0.25$ according to the metabolic theory of ecology (Brown et al. 2004). Accordingly, the smaller the organism, the higher the intrinsic maximum growth rate. This power law relationship holds over orders of magnitude and across a wide range or organisms (autotroph and heterotroph, 
eukaryotes and prokaryotes; e.g., Fenchel 1973) and implies that smaller organisms have the highest intrinsic growth (Fig. 2.12).

However, some cell components are non-scaleable, such as the genome and membrane, and consequently this power-law appears to break down in the range of nanoplankton $(2-20 \mu \mathrm{m})$. There is a trade-off between the size dependence of physiological traits (Ward et al. 2017). Burmaster's (1979) equation can be used to illustrate this:

$$
\mu_{\text {size }}=\frac{\mu_{\max } \cdot \theta_{\text {size }}}{\mu_{\max } \cdot Q_{\min }+\theta_{\text {size }}},
$$

where the maximum growth for a certain size $\left(\mu_{\text {size }}\right)$ depends on maximum nutrient uptake $\left(\theta_{\text {size }}\right)$, minimum cell quota $\left(Q_{\text {min }}\right)$ and theoretical maximum growth rate $\left(\mu_{\max }\right)$. Maximum nutrient uptake and requirement per cell scale positively with cell size (Fig. 2.2b, dashed blue line), while theoretical maximum growth rates scale negatively (Fig. $2.2 \mathrm{~b}$ solid blue line). The result is an optimum in growth rate for phytoplankton in the nanoplankton range (Fig. 2.2b, black line). Very small picoplankton cells have a low intrinsic growth rate that will increase with size because more volume is then available for catalysing and synthesizing. The intrinsic growth rate of microplankton cells will decrease with increasing size, as with most organisms, for multiple reasons, including the increase in intracellular transport distances between cellular machineries (Marañón et al. 2013).

\section{Box 2.2: Phytoplankton diversity, rate measurements and biogeo- chemical models}

The high number of different species in each water sample poses a challenge to link the species-specific growth parameters obtained in the laboratory with measurements of phytoplankton growth in the field and modelling of phytoplankton primary production for natural, mixed communities. Gross primary production is normally quantified by the production of oxygen, using either ${ }^{18} \mathrm{O}$-labelling or the differential evolution of oxygen in light and dark. The most common technique for measuring primary production is the ${ }^{14} \mathrm{C}$ labelling technique, but this method provides a result in between gross and net photosynthesis, depending on the duration of the incubation. Both approaches quantify primary production for the total community, rather than for specific species. Biological oceanographers have developed methods to quantify group-specific primary production, based on dilution approaches or the incorporation of isotopically labelled bicarbonate into biomarker or flow-cytometry separated groups of organisms (Laws 2013). These group-specific primary production measurements can be compared more directly to laboratory data. 
Biogeochemical modellers have explored a number of strategies to incorporate differences among phytoplankton species into their ecosystem models; e.g. the plankton functional group approach and phytoplankton size or trait based approaches. The former approach is limited to a few plankton groups that are representative for certain biogeochemical fluxes (e.g. $\mathrm{N}_{2}$ fixers, diatoms, small and large phytoplankton, coccoliths; Sarmiento and Gruber 2006). The size-based approach makes use of the systematic relationships between phytoplankton size and activity (e.g. Fig. 2.2), but some processes do not scale in a simple way with size. Trait- and genome-based approaches are the most recent, and they consider emergent phenomena (Follows et al. 2007). These approaches are instructive and needed to further our understanding and predictive capabilities in times of global change, but they are so far difficult to link with observations in the field.

\section{References}

Behrenfeld MJ, Falkowski PG (1997) A consumers' guide to phytoplankton primary production models. Limnol Oceanogr 42:1479-1491

Brown JH, Gillooly JF, Allen AP, Savage VM, West GB (2004) Toward a metabolic theory of ecology. Ecology 85:1771-1789

Burmaster DE (1979) The continuous culture of phytoplankton: mathematical equivalence among three steady-state models. Am Nat 113:123-134

Cloern JE (1987) Turbidity as a control on phytoplankton biomass and productivity in estuaries. Cont Shelf Res 7:1367-1381

Cloern JE (1991) Tidal stirring and phytoplankton bloom dynamics in an estuary. J Mar Res 49:203-221

Cloern JE, Grenz C, Vidergar LL (1995) An empirical model of the phytoplankton chlorophyll:carbon ratio - the conversion factor between productivity and growth rate. Limnol Oceanogr 40:1313-1321

Cole BE, Cloern JE (1987) An empirical model for estimating phytoplankton productivity in estuaries. Mar Ecol Prog Ser 36:299-305

Davidson K, Wood G, John EH, Flynn KJ (1999) An investigation of non-steady-state algal growth. I. An experimental model ecosystem. J Plankton Res 21:811-837

Droop MR (1970) Vitamin $B_{12}$ and marine ecology. V. Continuous culture as an approach to nutritional kinetics. Helgoländer Meeresun 20:629-636

Dunne JP, Sarmiento JL, Gnanadesikan A (2007) A synthesis of global particle export from the surface ocean and cycling through the ocean interior and on the seafloor. Glob Biogeochem Cycles, 21:GB4006. https://doi.org/10.1029/2006gb002907

Edwards KF, Thomas MK, Klausmeier CA, Litchman E (2016) Phytoplankton growth and the interaction of light and temperature: a synthesis at the species and community level. Limnol Oceanogr 61:1232-1244

Eppley RW (1972) Temperature and phytoplankton growth in the sea. Fish B.-NOAA 70:1063-1085

Falkowski PG (1981) Light-shade adaptation and assimilation numbers. J Plankton Res 3(2):203-216

Falkowski PG, Raven JA (1997) Aquatic photosynthesis. Blackwell 
Fenchel T (1973) Intrinsic rate of natural increase: the relationship with body size. Oecologia 14:317-326

Field CB, Behrenfeld MJ, Randerson JT, Falkowski PG (1998) Primary production of the biosphere: integrating terrestrial and oceanic components. Science 281:237-240

Follows MJ, Dutkiewicz S, Grant S, Chisholm SW (2007) Emergent biogeography of microbial communities in a model ocean. Science 315:1843-1846

Franks PJS (2015) Has Sverdrup's critical depth hypothesis been tested? Mixed layers vs. turbulent layers. ICES J Mar Sci 72:1897-1907

Gattuso JP, Gentilli B, Duarte C, Kleypass J, Middelburg JJ, Antoine D (2006) Light availability in the coastal ocean: impact on the distribution of benthic photosynthetic organism and contribution to primary production. Biogeosciences 3:489-513

Hardin G (1960) The competitive exclusion principle. Science 131:1292-1297

Hatton IA, McCann KS, Fryxell JM, Davies TJ, Smerlak M, Sinclair ARE, Loreau M (2015) The predator-prey power law: biomass scaling across terrestrial and aquatic biomes. Science, 349: aac6284. https://doi.org/10.1126/science.aac6284

Heip CHR, Goosen NK, Herman PMJ, Kromkamp J, Middelburg JJ, Soetaert K (1995) Production and consumption of biological particles in temperate tidal estuaries. Oceanogr Mar Biol Ann Rev 33:1-150

Huisman J, van Oostveen P, Weissing FJ (1999) Critical depth and critical turbulence: two different mechanisms for the development of phytoplankton blooms. Limnol Oceanogr 44:1781-1787

Hutchinson GE (1961) The paradox of the plankton. Am Nat 95:137-145

Kirk JTO (1992) The nature and measurement of the light environment in the ocean. In: Falkowski PG, Woodhead AD, Vivirito K (eds) Primary productivity and biogeochemical cycles in the sea. Environmental Science Research, vol 43. Springer, Boston

Laws EA (2013) Evaluation of in situ phytoplankton growth rates: a synthesis of data from varied approaches. Ann Rev Marine Sci 5:247-268

Marañón E, Cermeño P, López-Sandoval DC, Rodríguez-Ramos T, Sobrino C, Huete-Ortega M, Blanco JM, Rodríguez J (2013) Unimodal size scaling of phytoplankton growth and the size dependence of nutrient uptake and use. Ecol Lett 16:371-379

Middelburg JJ (2011) Chemoautotrophy in the ocean Geoph. Res Lett 38:L24604. https://doi.org/ $10.1029 / 2011$ GL049725

Morel A (1988) Optical modeling of the upper ocean in relation to its biogenous matter content (case I waters). J Geophys Res 93:10749-10768

Paerl HW, Hall NS, Calandrino ES (2011) Controlling harmful cyanobacterial blooms in a world experiencing anthropogenic and climatic-induced change. Sci Total Environ 409:1739-1745

Platt TC, Gallegos L, Harrison WG (1980) Photo-inhibition of photosynthesis in natural assemblages of marine phytoplankton. J Mar Res 38(1980):687-701

Sarmiento J, Gruber N (2006) Ocean biogeochemical dynamics. Princeton University Press, p 526

Siegel DA, Doney SC, Yoder JA (2002) The North Atlantic spring phytoplankton bloom and Sverdrup's critical depth hypothesis. Science 296:730-733

Smith SV (1981) Marine macrophytes as a global carbon sink. Science 211:838-840

Steele JH (1962) Environmental control of photosynthesis in the sea. Limnol Oceanogr 7:137-150

Soetaert K, Herman PMJ (2009) A practical guide to ecological modelling. Springer, p 372

Sverdrup HU (1953) On conditions for the vernal blooming of phytoplankton. Journal du Conseil International pour l'Exploration de la Mer 18:287-295

Ward BA, Marañón E, Sauterey B, Rault J, Claessen D (2017) The size dependence of phytoplankton growth rates: a trade-off between nutrient uptake and metabolism. Am Nat 189:170-177

Webb WL, Newton M, Starr D (1974) Carbon dioxide exchange of Alnus rubra: a mathemical model. Oecologia 17:281-291 
Open Access This chapter is licensed under the terms of the Creative Commons Attribution 4.0 International License (http://creativecommons.org/licenses/by/4.0/), which permits use, sharing, adaptation, distribution and reproduction in any medium or format, as long as you give appropriate credit to the original author(s) and the source, provide a link to the Creative Commons licence and indicate if changes were made.

The images or other third party material in this chapter are included in the chapter's Creative Commons licence, unless indicated otherwise in a credit line to the material. If material is not included in the chapter's Creative Commons licence and your intended use is not permitted by statutory regulation or exceeds the permitted use, you will need to obtain permission directly from the copyright holder.

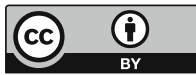

